\title{
CYLINDRICAL SHELLS MADE OF STAINLESS STEEL - INVESTIGATION OF POSTBUCKLING
}

\author{
Sebastian STEHR ${ }^{1}$, Natalie STRANGHÖNER ${ }^{1}$ \\ University of Duisburg-Essen, Essen, Germany
}

\begin{abstract}
The relevant load case of open thin-walled shells is often wind loading during construction. Because of the missing stabilization effect of the roof they show a very high sensitivity to buckling which results into higher wall thicknesses. As part of the European RFCS research project BiogaSS the Institute for Metal and Lightweight Structures of the University of Duisburg-Essen carried out investigations on open thin-walled tanks made of austenitic and duplex stainless steels under wind load to study a possible economic advantage which might be gained from the consideration of the elastic postbuckling behaviour. This contribution presents not only experimental and numerical results but also first recommendations regarding the range of possible buckling reduction factors which might be incorporated in future revisions of EN 1993-1-6 and EN 1993-4-2.
\end{abstract}

Keywords: cylindrical shells, stainless steel, wind loading, postbuckling, EN 1993-1-6

\section{INTRODUCTION}

In agriculture or biochemistry several liquids are stored in cylindrical steel tanks. In biogas production thin-walled tanks made of stainless steel are often used due to their advantages in durability, sustainability and economy.

These tanks are mainly designed for circumferential tensile stresses from hydrostatic internal liquid pressure. Hence, the tank walls are rather thin and radius/thickness ratios $r / t$ of 2500 up to 5000 in the upper courses are not unusual. However, during construction, where the stabilization effect of the roof is still missing, wind loading is often the relevant load case. In order to obviate global

${ }^{1}$ Corresponding author: University of Duisburg-Essen, Institute for Metal and Lightweight Structures, Universitätsstraße 15, 45141 Essen, tel. +492011832706, e-mail: ian.stehr@uni-due.de 
failure due to the very high sensitivity to buckling of the empty tank higher wall thicknesses are used and ring stiffeners at the top of the upper courses are obligatory.

Binder (1996) was one of those who made first suggestions for improvement based on the elastic postbuckling behaviour for the design of open thin-walled cylinders made of carbon steel under wind load. Based on these investigations a recent study on the postbuckling behaviour of open thin-walled tanks made of austenitic and duplex stainless steels under wind load has been carried out at the Institute of Metal and Lightweight Structures (IML) at the University of Duisburg-Essen (UDE) in the frame of the European RFCS research project BiogaSS. The results are presented in the following.

\section{STATE OF THE ART}

Tank design is based on the general principles and application rules of EN 1993-4-2 and the basic rules for plated steel shells of EN 1993-1-6. In the latter one, the buckling limit state design is based on a buckling stress design. Herein, the characteristic buckling stress $\sigma_{\mathrm{Rk}}$ is obtained by multiplying the characteristic yield strength $\mathrm{f}_{\mathrm{yk}}$ by a buckling reduction factor $\chi$ which depends on the relative slenderness $\bar{\lambda}$ of the shell, see Equation 2.1 a). For high slendernesses the behaviour is completely elastic and the characteristic buckling stress may alternatively be determined, see Equation $2.1 \mathrm{~b}$ ). Herein, $\alpha$ is the elastic imperfection reduction factor which depends on the fabrication tolerance quality class (FQC) of the structure and describes the amount of imperfections. $\sigma_{\mathrm{Rcr}}$ is the elastic critical buckling stress.
a) $\sigma_{R k}=\chi \cdot f_{y k}$
b) $\sigma_{R k}=\alpha \cdot \sigma_{R c r}$

Binder \& Schmidt (1997) formulated recommendations on the stability and the elastic postbuckling behaviour of open, ring stiffened cylindrical shells made of mild steel under uniform external pressure. Herein, the characteristic pressure resistance $\mathrm{q}_{\mathrm{Rk}}$ was determined for thin-walled cylindrical shells with radius/thickness ratios $\mathrm{r} / \mathrm{t} \leq 2500$ and length/radius ratios $0.3 \leq 1 / \mathrm{r} \leq 1.5$, see Equation 2.2.

$$
q_{R k}=\alpha^{*} \cdot q_{c r} \quad \text { with } \alpha^{*}=1.71-0.71 \cdot \frac{l}{r} \text { and } 0.65 \leq \alpha^{*} \leq 1.5
$$

$\mathrm{q}_{\mathrm{cr}}$ is the critical buckling pressure according to the former national German standard DIN 18800-4. $\alpha^{*}$ considers the elastic postbuckling behaviour based on the elastic imperfection reduction factor $\alpha$. 
The results of Binder \& Schmidt (1997) were based on a bilinear stress-strain behaviour of mild steels. One of the aim of the current investigations at IML was to evaluate how far the recommendations from Binder and Schmidt can be transferred to open tanks made of stainless steel as stainless steel shows an obvious nonlinear stress-strain-behaviour.

\section{EXPERIMENTAL SYSTEM}

The experimental investiagtions described in the following were part of the European RFCS research project 'BiogaSS-Innovative and competitive solutions using stainless steel and adhesive bonding in biogas production' funded by the European Research Fund for Coal and Steel. All tests were carried out at the Institute for Metal and Lightweight Structures of the University of DuisburgEssen.

The original concept of the experimental test setup was based on the idea of Esslinger \& Geier (1975) and already used by Binder and Schmidt for their investigations into the postbuckling behaviour of open thin-walled cylinders under external pressure. The shell specimens are mounted on a supporting structure attached to a water basin. Figure 1 shows the principle where the open shell is turned over and dipped into water to seal the cylinder and maintain the boundary conditions.
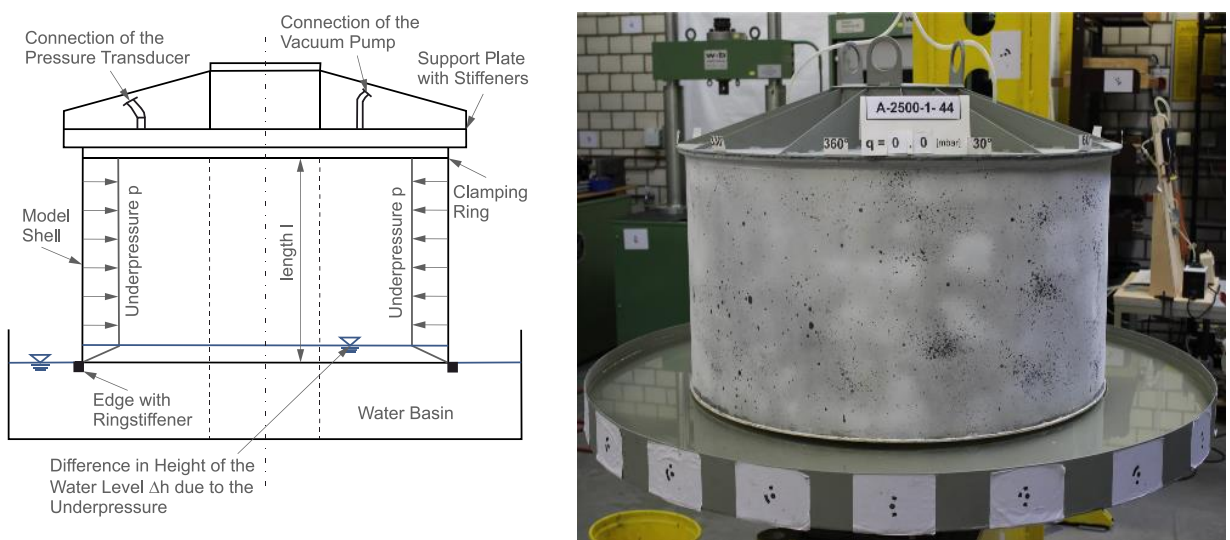

Fig. 1. Experimental system: principle drawing (left) and test setup of specimen A-2500-1-44 (VI) (right)

The underpressure in the shells was maintained during testing by means of a vacuum pump and monitored by a control unit. The difference between ambient and internal pressure of the shell was specified as the measured underpressure. It was applied in appropriate load steps of at least $0.1 \mathrm{mbar}$, sustained by means of a bypass, see Figure 2 . 
A hydrostatic internal pressure occurs at the bottom of the shell due to the difference in the height of the water level $\Delta \mathrm{h}$. This effect must be considered with regard to the stabilizing effect at the end of the postbuckling. At low vacuum levels this may be neglected, especially if considering that a pressure of $q=0.1$ mbar corresponds to a difference amounting to $\Delta \mathrm{h}=1.0 \mathrm{~mm}$.

A non-contact surface measurement of the shell model was carried out by means of photogrammetry due to the thin shell wall thicknesses of 0.1 to $0.2 \mathrm{~mm}$. Thus, photos of the shell were taken over $360^{\circ}$ from different height positions at each load and unload step. Three dimensional point cloud models of the specimens were created by means of a photogrammetric software. Herewith, the shape of the shell could be represented in Cartesian x-, y-, z-coordinates for each step. Based on the measured deformations, the postbuckling behaviour of the shells could be presented.

Although the rapid feasibility of this method is an advantage, increased expenses were caused by the pre-treatment of the model shells. The bare metal surface of the shells caused too strong reflections and therefore the specimens had to be sprayed with a special powder, suitable for this purpose. Unfortunately, the expected measurement accuracy $(0.05$ to $0.5 \mathrm{~mm})$ could not be achieved in the presented test series due to high reflections or too monotonous surfaces, see also section 6 .

\section{TEST SPECIMENS}

The shell specimens were made of austenitic (1.4301, for models I to VII) and austenitic-ferritic (duplex) stainless steel (1.4462, for models VIII and IX) according to EN 10088-4. Especially the highly nonlinear stress-strain behaviour of austenitic stainless steel compared to mild carbon steel is one reason for this selection.

The tested shell models were designed depending on the available material dimensions and the geometry of the test setup. Hence, radius/thickness ratios $\mathrm{r} / \mathrm{t}$ of 2500 and 5000 were chosen. Shells I to VII were made of austentic stainless steel with a radius of $r=500 \mathrm{~mm}$ and thicknesses $t$ of $0.2 \mathrm{~mm}$ and $0.1 \mathrm{~mm}$. The other shell models VIII and IX were made of duplex stainless steel with a radius of $375 \mathrm{~mm}$ and a thickness of $0.15 \mathrm{~mm}$. To examine two length/radius ratios 1/r of about 1.0 and 2.0 three different lengths were considered. Specimens I to III had a length 1 of $960 \mathrm{~mm}$, specimens IV to VII of $480 \mathrm{~mm}$ and specimens VIII to IX of $430 \mathrm{~mm}$, see Table 1 .

According to the top stiffener of a biogas tank, the shell models got stiffeners at their bottom side made of structural steel S235 according to EN 10025-2 except for model I (1.4462 according to EN 10088-4) and consisted of four quartercircular parts. They were soldered on the shell, except for model shell I, where 
the stiffener was glued. Due to the preliminary study of Binder (1997) the minimum second moment of area min $\mathrm{I}_{\mathrm{ts}}$ was defined as follows:

$$
I_{t s}=0.05 \cdot t^{3} \cdot h
$$

$\mathrm{t}$ is the thickness of the shell model and $\mathrm{h}$ describes the length $\mathrm{l}$ of the shell model, see Table 1 . The area of the cross section of each stiffener is indicated with $b_{R}$ for the width and $t_{R}$ for the thickness. For the first specimen (I) the stiffener was made with the minimum cross section area of $2 \mathrm{~mm} \times 2 \mathrm{~mm}$. Unfortunately, this specimen did not show local buckling failure as expected but global buckling failure. Hence, this test cannot be taking into account for further evaluations of the postbuckling behaviour. The area of the cross section of the stiffeners $\left(t_{R} \times b_{R}\right)$ needed to be increased for further testing. For this reason, the stiffeners of the specimens II to $\mathrm{V}$ had a cross section area of $5 \mathrm{~mm} \times 8 \mathrm{~mm}$ to achieve a favourable local buckling behaviour. However, due to the fact that these tests could be carried out without global failure, the underpressure was increased to a point at which the rising water in the tank was problematic, see section 3. Hence, to keep the water level at a minimum, the stiffener cross section area of specimens VI to VIII was reduced to $4 \mathrm{~mm} \times 4 \mathrm{~mm}$ and for specimen IX to $3 \mathrm{~mm} \times 3 \mathrm{~mm}$. The geometrical dimensions of all test specimens are summarized in Table 1, where the designation of the test specimens is defined as follows:

material $-\mathrm{r} / \mathrm{t}$ ratio $-1 / \mathrm{r}$ ratio $-\mathrm{t}_{\mathrm{R}} \mathrm{b}_{\mathrm{R}}$.

Table 1. Geometrical dimensions of the test specimens

\begin{tabular}{|l|c|c|c|c|c|}
\hline \multicolumn{1}{|c|}{ Designation } & \multicolumn{2}{|c|}{ Shell geometries } & & & \\
\hline & $\mathrm{r}$ & 1 & $\mathrm{t}$ & $1 / \mathrm{r}$ ratio & $\mathrm{r} / \mathrm{t}$ ratio \\
\hline & {$[\mathrm{mm}]$} & {$[\mathrm{mm}]$} & {$[\mathrm{mm}]$} & {$[-]$} & {$[-]$} \\
\hline A-2500-2-22 (I) & 500 & 960 & 0.20 & 1.92 & 2500 \\
\hline A-2500-2-58 (II) & 500 & 960 & 0.20 & 1.92 & 2500 \\
\hline A-5000-2-58 (III) & 500 & 960 & 0.10 & 1.92 & 5000 \\
\hline A-2500-1-58 (IV) & 500 & 480 & 0.20 & 0.96 & 2500 \\
\hline A-5000-1-58 (V) & 500 & 480 & 0.10 & 0.96 & 5000 \\
\hline A-2500-1-44 (VI) & 500 & 480 & 0.20 & 0.96 & 2500 \\
\hline A-5000-1-44 (VII) & 500 & 480 & 0.10 & 0.96 & 5000 \\
\hline D-2500-1-44 (VIII) & 375 & 430 & 0.15 & 1.15 & 2500 \\
\hline D-2500-1-33 (IX) & 375 & 430 & 0.15 & 1.15 & 2500 \\
\hline
\end{tabular}




\section{EXPERIMENTAL PROCEDURE}

In this study the elastic postbuckling behaviour of open thin-walled, edge stiffened shell structures made of austenitic and duplex stainless steel under distributed equivalent wind-like load was investigated. By means of photogrammetry the surface of the specimens was documented and deformations were examined. For the photogrammetric evaluation, photos were needed in three different directions of view $360^{\circ}$ around the tank.

Photos were taken from the initial state of the specimen at the beginning of each experiment. This first data set was taken as a reference value to investigate the deformations and to classify the tanks according to EN 1993-1-6. In the next step, the shell was loaded until a first buckle was visible. The underpressure was kept constant and a new set of photos was taken. To verify that this buckle was elastic, the shell was unloaded and documented again. In case that it was an elastic buckle and thus no deformations were visible in the unloaded stage, the shell specimen was loaded up again to the pressure level which was reached before. From this point the pressure was further increased stepwise constant until a difference in buckling occurred. Here, photos were taken before and after the unloading of the specimen. In principle, this procedure was carried out for each visible change in buckling.

If a plastic buckle was verified in an unloaded stage the major aim of the test was achieved. The underpressure was subsequently increased in larger steps, the specimen was unloaded rarely and the final state of collapse was also documented before the experiment was stopped, see exemplary Figure 2.

The presented experimental procedure was, in principle, the same for all specimens and was independently observed and reported by three persons.

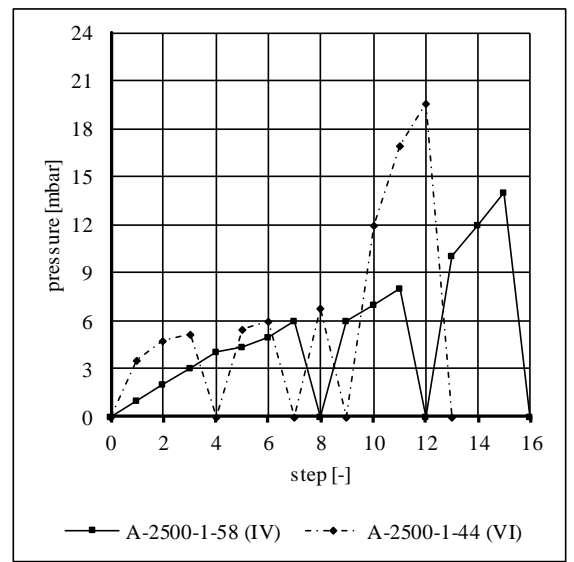

Fig. 2. Exemplary pressure curves of specimens A-2500-1-58 (IV) and A-2500-1-44 (VI), see Table 1. 


\section{PHOTOGRAMMETRIC DATA}

For each specimen, a set of photogrammetric data was generated from the photos taken. Irregular '3D point clouds' consisting of Cartesian $\mathrm{x}-, \mathrm{y}$ - and z-coordinates were provided from the applied photogrammetric method. In the first step of editing, these data were adjusted, so that the vertical cylinder axis corresponded to the z-axis. Afterwards, the Cartesian coordinates were converted into polar coordinates, a regular point grid was interpolated and the positions of the $\mathrm{x}$ - and $\mathrm{y}$-axes were aligned. Based on these point clouds and the protocols of observations the occurrence of buckles was verified accordingly. The occurrence and location of the first elastic buckle was specified by comparing the first loading stage including deformations with the first unloading stage afterwards. All unloading stages of a test were compared to specify the first plastic buckle.

Specimen A-2500-1-44 (VI) is chosen to explain the postbuckling behaviour due to its well identifiable buckling. A first buckle was documented at a pressure of $3.5 \mathrm{mbar}$. The pressure was increased up to $5.2 \mathrm{mbar}$ and after the first unloading stage nearly no deformation remained. The first elastic buckle was specified. The pressure was again increased up to $6,0 \mathrm{mbar}$ and also in the second unloading stage almost no deformations occurred. The first plastic deformations were visible in the third unloading stage after a previous pressure of $6.8 \mathrm{mbar}$. Between the angles $105^{\circ}-135^{\circ}$ and $150^{\circ}-180^{\circ}$ buckles were documented and these were also verified by the data, see Figure 3. Figure 4 shows the buckle between $105^{\circ}-$ $135^{\circ}$ and a selected vertical section at the angle $300^{\circ}$ with completely elastic buckling behaviour.
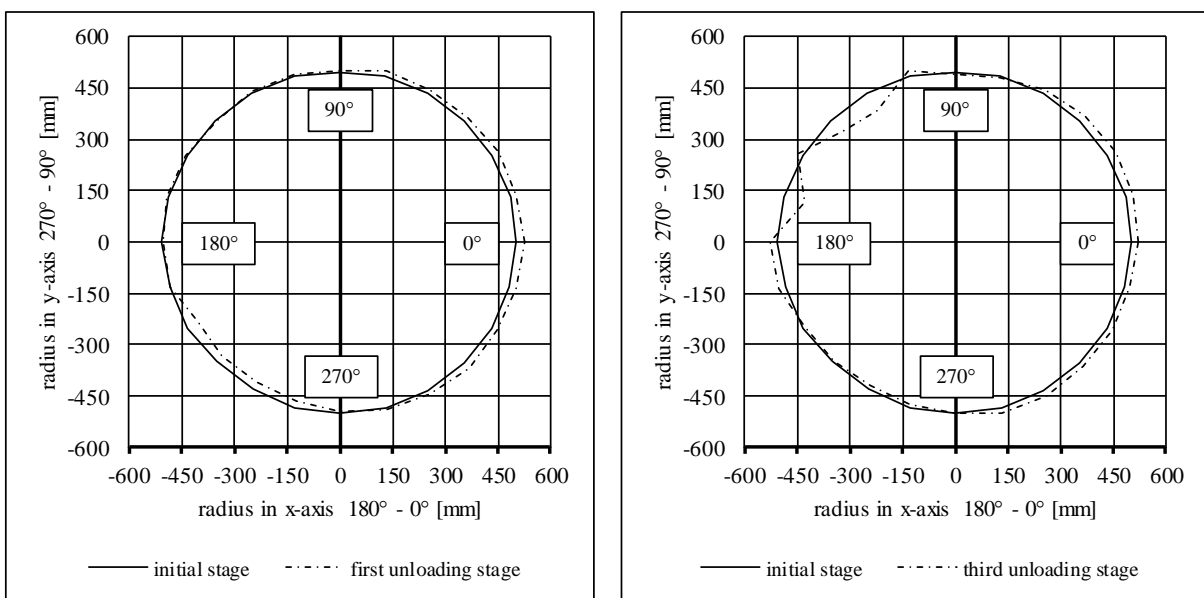

Fig. 3. Horizontal section at $221.0 \mathrm{~mm}$ height of specimen A-2500-1-44 (VI) for the first (left) and third (right) unloading stage (deformations five times scaled up) 

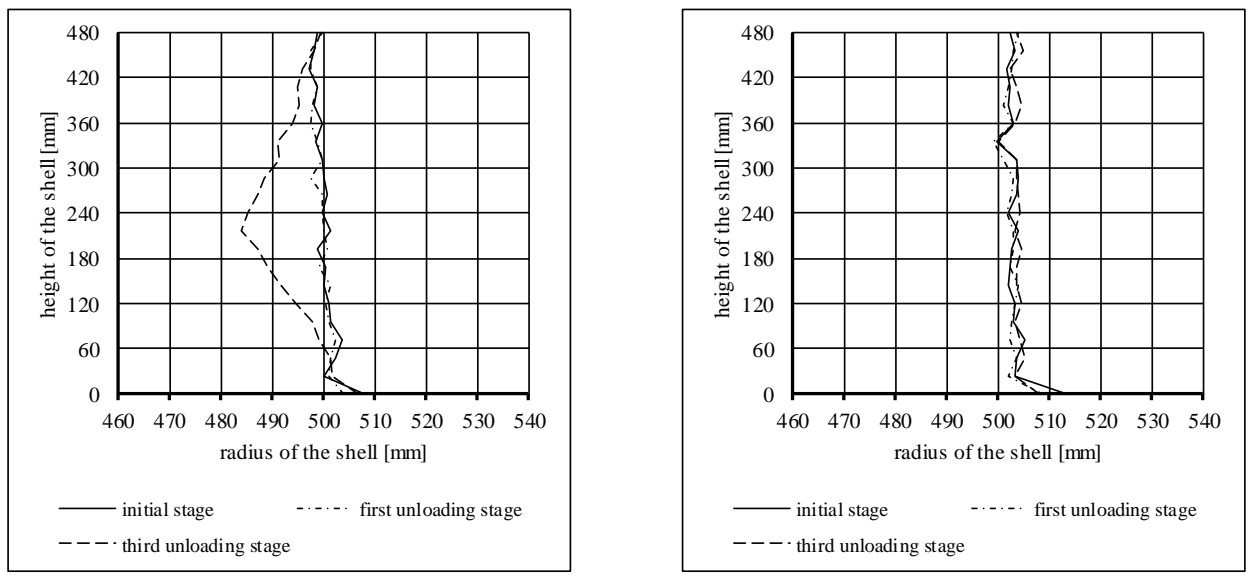

Fig. 4. Vertical section at $127^{\circ}$ angle (left) and at $300^{\circ}$ angle (right) of specimen A 2500-1-44 (VI) for the first and the third unloading stage

The deformation of the shell at $221 \mathrm{~mm}$ height and $127^{\circ}$ angle where the maximum plastic deformation occurred is presented in Figure 5. After the first and second load interval nearly no plastic deformations occurred which could be verified by the observations. The shown deformation during the first loading interval was not observed and has to be assumed to be a measurement error. Hence, the third unloading stage was defined as the end of the elastic postbuckling. As another example, Figure 5 shows the elastic deformation at 160 $\mathrm{mm}$ height and $90^{\circ}$ angle where no remaining deformations were visible after all three load intervals.
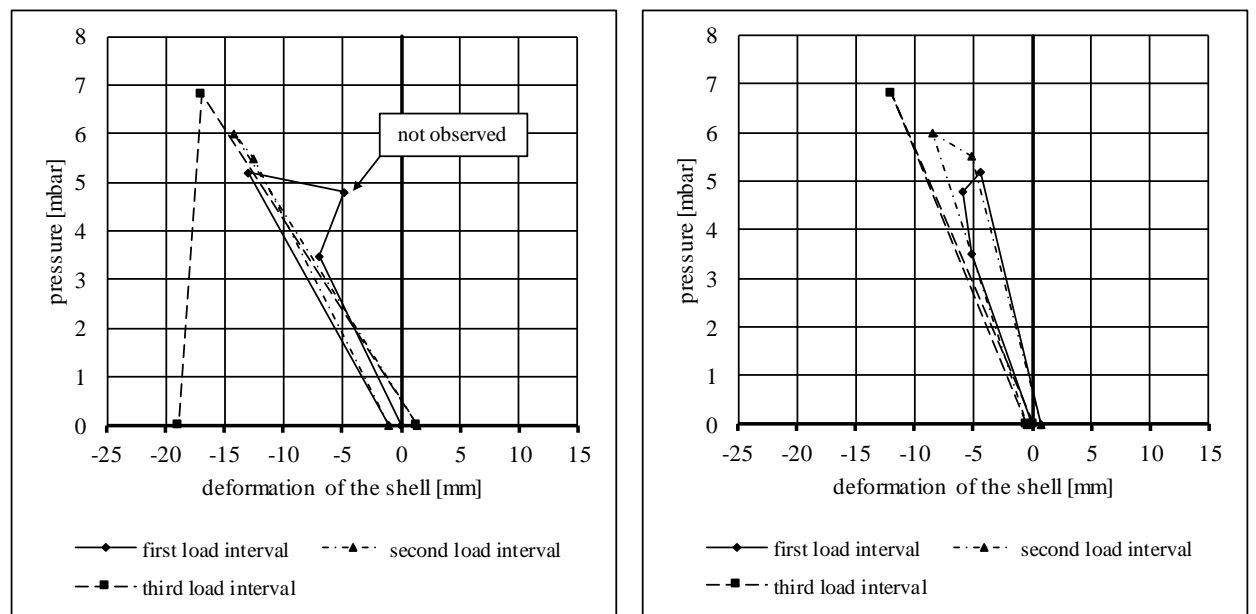

Fig. 5. Deformation at $221.0 \mathrm{~mm}$ height and $127^{\circ}$ angle (left) and at $160.0 \mathrm{~mm}$ height and $90^{\circ}$ angle (right) of specimen A-2500-1-44 (VI) 
Unfortunately, the desired accuracy of $0.5 \mathrm{~mm}$ could not be achieved for all measured deformations. Deviations of up to approximately $3.0 \mathrm{~mm}$ were observed. One reason for this behaviour was found in the surfaces of the shells which were still partially reflective or sprayed too monotonously. In summary, the data confirmed the observations taking into account the existing accuracy.

\section{RESULTS}

With the exception of specimen A-2500-22 (I), see section 4, the data of all tests were processed and interpreted. Pressures were documented at the level of the first elastic buckle $\mathrm{q}_{\mathrm{b}, \mathrm{el}}$ and of the first plastic buckle $\mathrm{q}_{\mathrm{b}, \mathrm{p}}$, see Table 2 .

Table 2. Documented pressures and calculated imperfection factors of the tested shells

\begin{tabular}{|l|c|c|c|c|c|c|}
\hline \multirow{2}{*}{ Designation } & \multicolumn{3}{|c|}{ Pressures } & \multicolumn{3}{c|}{ Imperfection factors (Ratio) } \\
\hline & $\mathrm{q}_{\mathrm{b}, \mathrm{el}}$ & $\mathrm{q}_{\mathrm{b}, \mathrm{pl}}$ & $\mathrm{q}_{\theta, \mathrm{Rcr}}$ & $\begin{array}{c}\alpha_{\theta}=\mathrm{q}_{\mathrm{b}, \mathrm{el}} / \\
\mathrm{q}_{\theta, \mathrm{Rcr}}\end{array}$ & $\begin{array}{c}\alpha^{*}{ }_{\theta}=\mathrm{q}_{\mathrm{b}, \mathrm{pl}} / \\
\mathrm{q}_{\theta, \mathrm{Rcr}}\end{array}$ & $\alpha^{*}{ }_{\theta} / \alpha_{\theta}$ \\
\cline { 2 - 8 } & {$[\mathrm{mbar}]$} & {$[\mathrm{mbar}]$} & {$[\mathrm{mbar}]$} & {$[-]$} & {$[-]$} & {$[-]$} \\
\hline A-2500-2-58 (II) & 2.1 & 3.9 & 3.8 & $0.55(\mathrm{C})$ & 1.02 & 1.85 \\
\hline A-5000-2-58 (III) & 0.4 & 1.0 & 0.7 & $0.57(\mathrm{C})$ & 1.43 & 2.49 \\
\hline A-2500-1-58 (IV) & 4.4 & 6.0 & 7.7 & $0.57(\mathrm{C})$ & 0.78 & 1.37 \\
\hline A-5000-1-58 (V) & 0.6 & 0.8 & 1.3 & $0.46(-)$ & 0.61 & 1.33 \\
\hline A-2500-1-44 (VI) & 3.5 & 6.8 & 7.7 & $0.46(-)$ & 0.88 & 1.91 \\
\hline A-5000-1-44 (VII) & 0.6 & 0.8 & 1.3 & $0.46(-)$ & 0.61 & 1.33 \\
\hline D-2500-1-44 (VIII) & 3.2 & 12.0 & 6.5 & $0.49(-)$ & 1.84 & 3.76 \\
\hline D-2500-1-33 (IX) & 2.8 & 11.0 & 6.5 & $0.43(-)$ & 1.69 & 3.93 \\
\hline
\end{tabular}

First, to enable a classification into the fabrication tolerance quality classes according to EN 1993-1-6 the pressure of the elastic buckle $q_{b, e l}$ was divided by the ideal circumferentially buckling pressure $\mathrm{q}_{\theta, \mathrm{Rcr}}$. As described in section 2 the ideal circumferentially buckling pressure $\mathrm{q}_{\theta, \mathrm{Rcr}}$ was calculated according to EN 1993-1-6, Annex D for each specimen. For fabrication tolerance quality class C the minimum circumferential elastic imperfection reduction factor $\alpha_{\theta}=\mathrm{q}_{\mathrm{b}, \mathrm{el}} / \mathrm{q}_{\theta, \mathrm{Rcr}}$ becomes 0.5 and 0.65 for Class B.

The data of the specimens II to IV obtained circumferential elastic imperfection reduction factors $\alpha_{\theta}$ higher than 0.5 but less than 0.65 , thus these specimen could be assigned to Class C. Circumferential elastic imperfection reduction factors $\alpha_{\theta}$ less than 0.5 were calculated for specimens V to IX, thus these specimen could not be assigned anymore to a fabrication tolerance quality class according to EN 1993-1-6.

In reference to the $\alpha^{*}{ }_{\theta}$ value specified by Binder (1996), see also section 2, the pressure of the first plastic buckle $\mathrm{q}_{\mathrm{b}, \mathrm{pl}}$ was divided by $\mathrm{q}_{\theta, \mathrm{Rcr}}$. This ratio is the so called 'plastic imperfection factor' in this paper and is intended to take into 
account the favourable postbuckling behaviour in the design of tank structures. For specimens II and III made of austenitic stainless steel and with a length/radius ratio $1 / \mathrm{r}=1.92$ a 'plastic imperfection factor' higher or almost equal than 1.0 was calculated. Here, specimen III (A-5000-2-58) - with a comparatively small wall thickness - yields an $\alpha^{*}{ }_{\theta}$ value of about 1.5. Specimens IV to VII, also made of austenitic stainless steel and with $1 / \mathrm{r}=0.96$, showed $\alpha^{*}{ }_{\theta}$ values between 0.6 and 0.9 . The specimens VIII and IX made of austenitic-ferritic (duplex) stainless steel with $1 / r=1.15$ differ only in the dimension of the stiffener and showed the highest $\alpha^{*}{ }_{\theta}$ values up to about 1.8. In summary, a decisive influence of the top stiffener could not be recognized and the values of the calculated "plastic imperfection factors' $\alpha^{*}{ }_{\theta}$ are consistently higher than the achieved elastic imperfection reduction factors $\alpha_{\theta}$, especially for the shell models made of duplex stainless steel, see Figure 6.

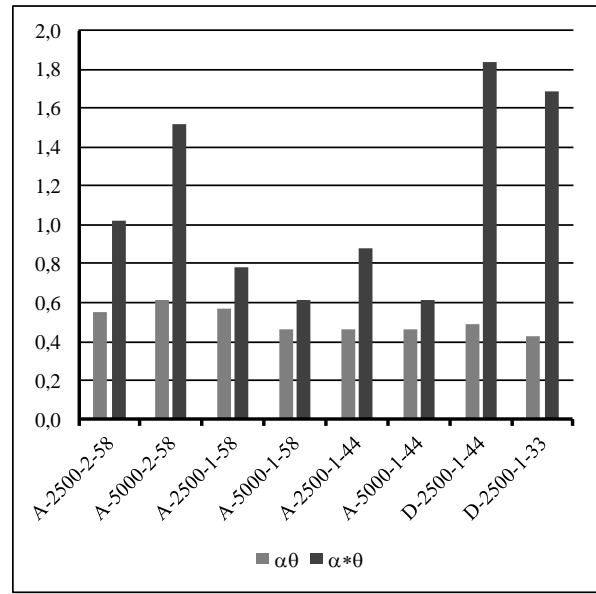

Fig. 6. Achieved circumferential elastic imperfection reduction factors $\alpha_{\theta}$ and 'plastic imperfection factors' $\alpha^{*}{ }_{\theta}$ for the tested shell models

Considering the postbuckling behaviour by a 'plastic imperfection factor' $\alpha^{*}{ }_{\theta}$ the austenitic shell models achieved an enhancement compared to the elastic imperfection reduction factors $\alpha_{\theta}$ of about 1.3 to 2.5. However, the duplex shells achieved enhancements of up to 3.9. This represents an increase of nearly $400 \%$.

\section{CONCLUSIONS}

The presented investigations showed that an extension of design limitation to first plastic rather than first elastic buckling might result in a higher design resistance for shell structures with high relative slendernesses. Thus, the consideration of the elastic postbuckling behaviour of open thin-walled shells made of stainless steel might result in an advantage in the design process of thin walled shell structures. 
Further evaluations and numerical parameter studies are currently carried out at the Institute for Metal and Lightweight Structures at the University of DuisburgEssen in order to generate general recommendations which might be incorporated in future revisions of EN 1993-1-6 or EN 1993-4-2 to improve the economical design of tanks.

\section{ACKNOWLEDGEMENTS}

The research leading to these results has received funding from the European Union's Research Fund for Coal and Steel (RFCS) research programme under grant agreement $\mathrm{n}^{\circ}$ RFSR-CT-2012-00035 for the research project 'Innovative and competitive solutions using stainless steel and adhesive bonding in biogas' (BiogaSS).

\section{REFERENCES}

1. Binder B.: Stabilität einseitig offener, verankerter, aussendruckbelasteter Kreiszylinderschalen unter besonderer Berücksichtigung des Nachbeulverhaltens, PhD-Thesis, University-GH Essen, Fachbereich 10, 1996.

2. Binder B., Schmidt H.: Experimentelle Untersuchungen zum elastischen Beul- und Nachbeulverhalten extrem dünnwandiger, einseitig offener Kreiszylinderschalen mit und ohne Randversteifung unter konstantem Manteldruck, Research Report 71, University-GH Essen, Fachbereich 10, 1997.

3. DASt-Richtlinie 017 Entwurf 1992: Beulsicherheitsnachweise für Schalen. Deutscher Ausschuß für Stahlbau, Stahlbau-Verlagsgesellschaft Köln.

4. DIN 18800-4:2008-11. Steel structure - Part 4: Stability - Analysis of safety against buckling of shells.

5. EN 1993-1-4:2006. Eurocode 3: Design of steel structures - Part 1-4: General rules - Supplementary rules for stainless steels.

6. EN 1993-1-6:2007 + AC:2009. Eurocode 3: Design of steel structures Part 1-6: Strength and stability of shell structures.

7. EN 1993-4-2:2007 + AC:2009. Eurocode 3: Design of steel structures - Part 4-2: Tanks.

8. EN 10025-2:2004. Hot rolled products of structural steels - Part 2: Technical delivery conditions for non-alloy structural steels.

9. EN 10088-4:2009. Stainless steels - Part 4: Technical delivery conditions for sheet/plate and strip of corrosion resisting steels for construction purposes.

10. Esslinger M., Geier B.: Postbuckling behaviour of structures, Wien/New York, Springer-Verlag, 1975. 
11. Franke A. A.: Vergleichende experimentelle und numerische Untersuchungen zur Ermittlung von zusätzlichen Faktoren unter der Berücksichtigung des elastischen Nachbeulverhaltens von offenen dünnwandigen Kreiszylinderschalen aus nichtrostendem Stahl unter Windbelastung im Bauzustand, Master-Thesis, Essen, University of Duisburg-Essen, Institute for Metal and Lightweight Structures, 2015.

12. Jejji A.: Zum Nachbeulverhalten von zylindrischen Tanks aus nichtrostenden Stählen unter Windbelastung im Bauzustand, Master-Thesis, Essen, University of Duisburg-Essen, Institute for Metal and Lightweight Structures, 2013.

13. Lange H., Schmidt H.: Ergänzende experimentelle Untersuchungen zum Nachbeulverhalten dünnwandiger, einseitig offener, randversteifter Kreiszylinderschalen unter konstantem und windähnlichem Manteldruck, Research Report 78, University-GH Essen, Fachbereich 10, 1998.

14. Schmidt H.: Stabilität stählerner Schalentragwerke, in: Stahlbau-Kalender 2009, edt. U. Kuhlmann, 2009, p. 529-612.

15. Schmidt H., Binder B., Lange H.: 1996a. Postbuckling design of extremely thin walled cylindrical tanks, European Workshop, Thin-Walled Steel Structures, Krzyzowa, Poland, 1996.

16. Schmidt H., Binder B., Lange, H.: Windbuckling design of open thin-walled cylindrical tanks, Advances in Steel Structures, ICASS'96, 1996.

17. Schmidt H., Binder B., Lange, H.: Postbuckling strength design of open thinwalled cylindrical tanks under wind load, in: Thin-Walled Structures 31 (1998), p. 203-220, 1998.

18. Song Y.: Vergleichende numerische Untersuchungen zum Einfluss von verschiedenen Ersatzimperfektionen auf das Nachbeulverhalten von offenen dünnwandigen Kreiszylinderschalen aus nichtrostendem Stahl unter Windbelastung im Bauzustand, Master's thesis, Essen, University of Duisburg-Essen, Institute for Metal and Lightweight Structures, 2014.

\section{POWŁOKI CYLINDRYCZNE ZE STALI NIERDZEWNEJ - BADANIE STANÓW POKRYTYCZNYCH}

\section{Streszczenie}

Najbardziej adekwatnym przypadkiem obciążenia otwartych, cylindrycznych powłok cienkościennych jest obciążenie wiatrem podczas wznoszenia powłoki. Wobec braku stabilizującego efektu dachu, powłoki wykazują bardzo dużą wrażliwość na wyboczenie, która prowadzi do konieczności zwiększenia grubości ścian powłoki. Instytut Konstrukcji Lekkich i Metalowych Uniwersytetu Duisburg-Essen przeprowadził badania stateczności 
otwartych zbiorników cienkościennych wykonanych z nierdzewnych blach ze stali austenicznej i ze stali duplex poddanych działaniu obciążenia wiatrem. Celem tych badań było określenie możliwych korzyści ekonomicznych wynikających z uwzględnienia sprężystych stanów pokrytycznych. Badania te były częścią Europejskiego Projektu RFCS BiogaSS. Prezentowana praca przedstawia nie tylko wyniki badań eksperymentalnych i analiz numerycznych, lecz także pierwsze propozycje zaleceń dotyczących zakresu redukcyjnych współczynników wyboczeniowych, które w przyszłości mogą być włączone do norm EN 1993-1-6 i EN 1993-4-2.

Słowa kluczowe: $\quad$ powłoka cylindryczna, stal nierdzewna, obciążenie wiatrem, stany pokrytycznych, EN 1993-1-6.

Editor received the manuscript: 02.07.2016 